\title{
Value Creation of Enterprise Risk Management: Evidence from Malaysian Shariah-Compliant Firms
}

\author{
Enny Nurdin Sutan Maruhun, Ruhaya Atan, Sharifah Norzehan Syed Yusuf, \\ Rahayu Abdul Rahman, Wan Razazila Wan Abdullah
}

To Link this Article: http://dx.doi.org/10.6007/IJARBSS/v11-i10/11197

DOI:10.6007/IJARBSS/v11-i10/11197

Received: 05 August 2021, Revised: 08 September 2021, Accepted: 28 September 2021

Published Online: 16 October 2021

In-Text Citation: (Maruhun et al., 2021)

To Cite this Article: Maruhun, E. N. S., Atan, R., Yusuf, S. N. S., Rahman, R. A., \& Abdullah, W. R. W. (2021). Value Creation of Enterprise Risk Management: Evidence from Malaysian Shariah-Compliant Firms. International Journal of Academic Research in Business and Social Sciences, 11(10), 922 - 938.

Copyright: (c) 2021 The Author(s)

Published by Human Resource Management Academic Research Society (www.hrmars.com)

This article is published under the Creative Commons Attribution (CC BY 4.0) license. Anyone may reproduce, distribute, translate and create derivative works of this article (for both commercial and non-commercial purposes), subject to full attribution to the original publication and authors. The full terms of this license may be seen at: http://creativecommons.org/licences/by/4.0/legalcode

Vol. 11, No. 10, 2021, Pg. 922 - 938

Full Terms \& Conditions of access and use can be found at http://hrmars.com/index.php/pages/detail/publication-ethics 


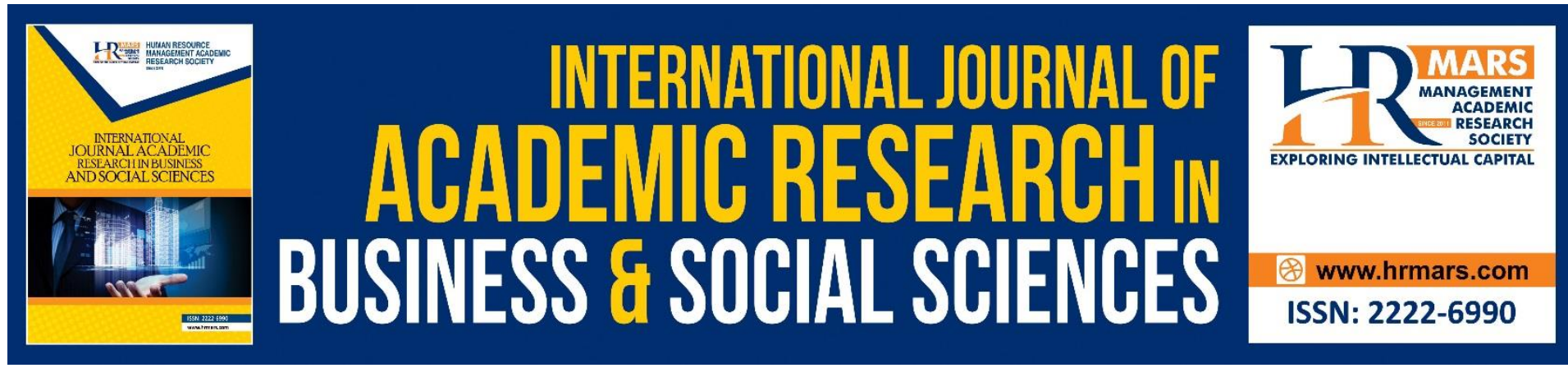

\title{
Value Creation of Enterprise Risk Management: Evidence from Malaysian Shariah-Compliant Firms
}

\author{
Enny Nurdin Sutan Maruhun \\ Faculty of Accountancy Universiti Teknologi MARA (UiTM) Perak, Tapah Campus, Malaysia \\ Phone No: 05-4067463 \\ Email: ennyn786@uitm.edu.my
}

Ruhaya Atan, Sharifah Norzehan Syed Yusuf

Accounting Research Institute Universiti Teknologi MARA Shah Alam, Malaysia

Email: ruhaya@uitm.edu.my, shari893@uitm.edu.my

\begin{abstract}
Rahayu Abdul Rahman
Faculty of Accountancy Universiti Teknologi MARA (UiTM) Perak, Tapah Campus, Malaysia

Email: rahay916@uitm.edu.my

\section{Wan Razazila Wan Abdullah}

Faculty of Accountancy Universiti Teknologi MARA (UiTM) Perak, Tapah Campus, Malaysia

Email:wanrazz@uitm.edu.my
\end{abstract}

\begin{abstract}
Enterprise risk management (ERM) has emerged as an important new corporate risk management practice. The main objective of ERM is to create shareholders value and increase firm value by reducing various costs involved with highly volatile cash flows particularly to mitigate financial distress costs and underinvestment problems. However, findings of prior studies show mixed results on the ability of ERM to create value for firm. Thus, this study aimed at examining the impact of ERM implementation to maximising shareholders value which is measured by financial distress costs, underinvestment problems and firm value among Malaysian Shariah-compliant public-listed companies. This is a cross-sectional study that used quantitative methodology approach. Two types of data were gathered that are (i) primary data; through survey questionnaire and (ii) secondary data; hand-picked from firms' annual report. Findings of this study demonstrate that ERM implementation has a significant impact to financial distress cost and underinvestment problem. However, the results do not find an impact of ERM implementation to firm value. The outcome of this study would be useful for firms to have a better understanding on the impact of ERM implementation to shareholders value where empirical findings of this study confirmed that ERM
\end{abstract}


implementation is able to increase shareholders value through reduction of financial distress cost and underinvestment problem.

Keywords: Enterprise Risk Management, Financial Distress, Shariah-Compliant Firms, Malaysia

\section{Introduction}

Organizations are regularly confronted by events that affect the execution of their strategies and achievement of their objectives. These events can have a negative impact (risks), a positive impact (opportunities), or a mix of both risks and opportunities. The 2008 global financial crisis has intensified and refocused interest on risk and the environment of systems that operate to manage those risks. In the light of the financial crisis, there is a need for appropriate risk management, planning, and control where organizations need to reassess their governance structure to ensure adequate risk management is in place. This crisis has demonstrated weaknesses in traditional risk management styles and has proven the failure of the traditional silo-based risk management to transmit information about risk exposures to management (Marc, Sprčić, \& Žagar, 2018). Therefore, organizations need to transform their risk management technique from silo-based approach to holistic approach. As a result, Enterprise Risk Management (ERM) was introduced as a response to an increasing pressure received by organizations to manage risks comprehensively (Lundqvist, 2014).

Despite the claim that ERM is an effective response to risk management challenges and has received growing attention from business community, only a minority of firms are adopting the system. In Malaysia, previous survey carried out among the main board listed companies on Bursa Malaysia shows that ERM practices were still at an early stage of implementation. Daud, Yazid, and Hussin (2010) conducted ERM survey among Malaysian public-listed companies (PLCs) and concluded that ERM practices among Malaysian PLCs was still at infancy. The finding is supported by Ping and Muthuveloo (2015), which found that only $21.4 \%$ of the Malaysian PLCs had been implementing ERM extensively while $44.7 \%$ of the companies implemented ERM to a somewhat moderate extent. The statistics raise questions as to why some firms implement an ERM program while others do not; and whether ERM programs can actually create value once implemented.

As stated by Institute of Internal Auditors (IIA), the main goal of ERM is to create, protect, and enhance shareholders value by managing risks that hinder achievement of an organization's objectives (Sobel \& Reding, 2004). Lam (2014) argues that risk management could benefit organizations if the practises can (i) reduce earnings volatility, (ii) maximise shareholders value, and (iii) promote financial stability. Furthermore, the Committee of Sponsoring Organizations of Treadway Commission (COSO) highlights that the fundamental principle of ERM is to provide value for stakeholders as it deals with risks and opportunities affecting value creation or preservation. COSO argues that firms could maximize values if the management sets strategies to balance growth and risks and if management correctly uses resources as it pursues objectives and manages the risk (COSO, 2004).

In order to understand the impact of ERM implementation to value creation, this study focuses on shareholders value maximising theory. The relationship between risk management and shareholders value maximising has long been debated among academics. Shareholders value maximising theory highlights that the most important benefits derived from ERM activities is that ERM has value creating ability, which is, the capacity to increase firm value (Liebenberg \& Hoyt, 2003; Miccolis \& Shah, 2000; Songling, Ishtiaq, \& Anwar, 2018). This theory believes ERM implementation leads to various tangible and intangible advantages for 
organizations such as improving risk/returns profile, strengthening management's confidence in business operations and risk monitoring (Shad \& Lai, 2019). In addition, shareholders value maximising theory claims that ERM can reduce financial distress costs and underinvestment problem facing a firm which could create value to a firm (Dionne \& Garand, 2003; Lechner \& Gatzert, 2018; Stulz, 1996).

The existing empirical studies find mixed evidence on the ability of ERM to create value for firm. Despite the substantial interest in ERM from various parties, there has an absence of clear empirical evidence on the impacts of ERM on value creation. Beasley et al. (2008) asserted that albeit the significant rise in the number of firms implementing ERM, little is understood on the relation between ERM and firm value. Previous studies that assessed the impacts of ERM to firm value have yielded mixed findings such as shown in studies by Lai and Kashif (2017); Ai, Chen, and Zhao (2014); Farrell and Gallagher (2015); Beasley, Branson, and Pagach (2015) that suggest ERM implementation is an important factor to enhance the firms value. In the contrary, Baxter, Bedard, Hoitash, and Yezegel (2013); Quon, Zeghal, and Maingot (2012); Lin, Wen, and Yu (2012) found that ERM implementation did not affects firm value.

The mixed findings are worrisome since the notion that ERM is a value-creating program is important for its development to continue. Thus, the main objectives of this study are to (i) evaluate whether ERM have an impact on shareholders value that are proxied by financial distress cost and underinvestment problem among Malaysian Shariah-compliant public listed firms and (ii) examine whether ERM creates value to Malaysian Shariah-compliant public listed firms. Shariah-approved firms are firms that conduct activities which are not contrary to the Islamic principles and have been approved by the Shariah Advisory Council (Othman, Thani \& Ghani, 2009). Shariah-compliant companies are the focus of this study because of the rapid growth of Islamic Capital Market (ICM) in Malaysia. This development is in line with the aspiration to develop Malaysia as a leading international and regional hub of Islamic Finance in the Asian region.

\section{Literature Review}

\section{Development of Risk Management Practices}

The word "risk" in English is derived from an Italian word risicare, which means, "to dare" and in Chinese, character risks are represented by two symbols: "danger" and "opportunity". These two symbols imply that risk is a strategic combination of vulnerability and opportunity (Aabo, Fraser, \& Simkins, 2010; Simkins \& Ramirez, 2008). In Islamic finance, the word risk is described as mukhatarah and originated from an Arabic word khatar, which implies several meanings such as 'exposure', 'fear of destruction' or 'impending doom'. In general, risk is defined simply as "the possibility of loss or injury" (Harner, 2010). In business context, risk is referred to as unanticipated or negative variations in business outcomes variables such as revenues, costs, profit and market shares (Miller, 1992). Risks are damaging events that cannot be avoided by organizations and could lead to an end of a business if improperly managed and mitigated (Iswajuni, Manasikana, \& Soetedjo, 2018). Therefore, managing risk is a crucial activity of a firm and corporate risk management is an important element of a firm's overall business strategy.

In the early stage of formal risk management practices, firms were more focused on managing pure risks (hazard risks) where these downside risks were transferred to third party such as insurance firms (Arena, Arnaboldi, \& Azzone, 2011; Dickinson, 2001). Pagach and Warr, (2010) state that traditional risk management (TRM) practices concentrated on offsetting 
identified risks either through purchasing insurance or through engaging in derivatives. TRM has been considered as a compartmentalized and uncoordinated risk management technique where risk managers focusing on managing pure risks while the treasury department concentrated on hedging financial risks (McShane, Nair, \& Rustambekov, 2011) .

The onset of 21st century saw the start of financial crisis and corporate scandals around the globe, beginning with Enron's downfall and followed by a series of massive financial catastrophes involving firms such as Bristol-Myers Squibb, Qwest, Xerox, WorldCom, and Global Crossing (Simkins \& Ramirez, 2008). Organizations were surprised by the impact of the crisis that paralyzed their business operations due to limited effective techniques available in communicating or responding to the fast changing financial landscape. This crisis highlighted the significant failure in TRM practices and showed weaknesses in firms' governance system particularly financial risk management. As a result, the initiation of a more comprehensive risk management technique was seen as inevitable (Harner, 2010). Since then, risk management practice had evolved from fragmented and insurance-based to holistic-based. Organizations began to adopt a comprehensive and coherent risk management approach.

This new approach is popularly known as Enterprise Risk Management (ERM). The most cited ERM definition in the literature is by the Committee of Sponsoring Organisations of the Treadway Commission (COSO). COSO (2004) defines ERM as "a process, effected by an entity's board of directors, management, and other personnel, applied in strategy setting and across the enterprise, designed to identify potential events that may affect the entity, and manage risks to be within its risk appetite, to provide reasonable assurance regarding the achievement of entity objectives" (p.8). ERM is developed based on the idea that risk management is a transversal process that addresses all uncertainties that could prevent the achievement of firm's objectives (Arena et al., 2011). ERM offers firms a comprehensive and holistic risk management practice by adopting a systematic and consistent method of managing total risk and it is presumed to lower firm's overall risk of failure and thus increase firm performance (Gordon, Loeb, \& Tseng, 2009). The primary aim of ERM is to increase the prospect that strategic objectives are realized and shareholders' value is preserved and enhanced. ERM should improve corporate sustainability and lower a company's overall risk of failure, making positions for other stakeholders more secure and valuable. (Marc et al., 2018). Furthermore, ERM is claimed as an integrated way of measuring, understanding and controlling risks facing a firm. It is also a management tool that identifies profitable opportunities that can enhance shareholders' wealth (Altuntas, Berry-Stolzle, \& Hoyt, 2011). Figure I show the evolution of risk management practices, which started with hazard and credit to holistic risk management.

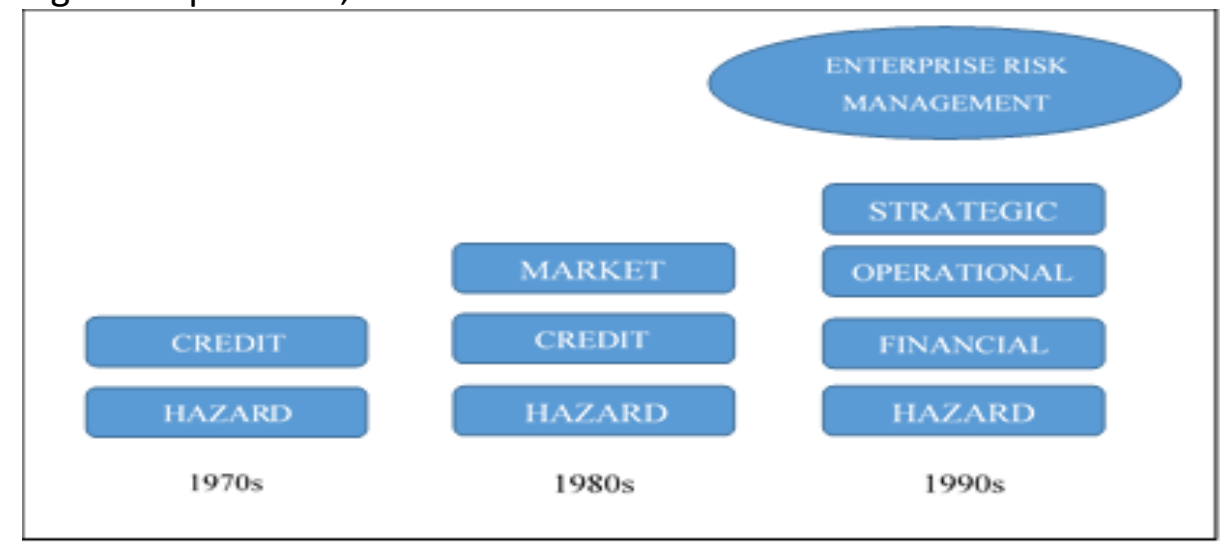

Figure I. Evolution of Risk

Source: Shenkir \& Walker (2008) 


\section{Risk Management Theory}

Enterprise risk management is a new discipline of risk management. Although there is a significant rise in the number of firms adopting ERM, little is understood on the theory that influences ERM implementation and the relation between ERM and firm value (Beasley, Pagach, \& Warr, 2008). Thus, this study uses shareholders value maximisation theory as foundations to develop the theoretical framework, and to examine whether ERM has an effect on the firm value. In general, shareholders value maximization theory measures how successful firm enriches its shareholders and maximising shareholders' wealth has become the main focus of firms. The importance of maximising shareholders value was emphasized with the issuance of a document by OECD titled "Principles of Corporate Governance" in 1999, which stresses that good corporate governance practices will create market confidence and business integrity, which in turn is essential for companies that need access to equity capital for long term investment (OECD, 2014). One of the strategies that can achieve shareholders' value maximisation is through effective risk management practices, hence, the implementation of ERM system.

Stulz (1996) in his seminal paper explains how risk management practices can create and increase firm value. A firm with randomly fluctuating cash flows and has debt at the same time could eventually face bankruptcy. Bankruptcy costs are real resource costs when firm needs to pay lawyers and court and the present value of these costs would reduce the firm value. Therefore, to eliminate bankruptcy costs, firm implements risk management program that can stabilize the cash flow and set present value of bankruptcy costs to zero and accordingly this increases firm value. The same argument extends to distress costs. A financially weak firm that has difficulty in raising fund for investment commonly experiences distress costs. The inability to undertake valuable investments is a real cost to a firm. As such, through risk management program such as ERM, firms may mitigate financial distress costs that reduce present value of distress costs and eventually increase firm value.

ERM creates value through aggregating of risks into portfolios, then hedging the residual risk. This technique is more efficient and value maximizing than dealing with each risk independently as in silo-approach (McShane et al., 2011). Furthermore, Marc et al (2018) propose that ERM should improve corporate sustainability and lower a company's overall risk of failure to enhance shareholders value. In ERM, the focus is shifted towards a more offensive handling by integrating ERM into the corporate strategy and the decision process and is explicitly intended to contribute to increasing shareholder value (Gatzert \& Martin, 2015).

\section{Risk Management from Islamic Perspective and Shariah-Compliant Firms}

The notion of risk taking is an important and a core principal in Islamic financial transactions. Risk is an important element in economic activities and must be taken to create wealth and value. It is argued that obtaining profit without assuming business risk is not permissible. Total elimination of risk in financial transaction, which is 'zero risk' may result in the income derived becoming illegitimate. The principle of risk taking from Islamic perspective implies that the contracting parties in a business transaction bear the fundamental business risk and liability. According to Shariah, the profit is only legitimate if it assumes a proportionate risk and should not be gained from risk free contract. Risk taking principle is based on the principle of liability that forms the legitimacy of receiving profit (Agha \& Sabirzyanov, 2015).

Risk management is an important activity in Shariah-compliant firm and risk management practices in Islamic perspectives are different from conventional framework. From 
conventional point of view, the primary focus of corporate risk management is to manage and minimize risk, which is limited to economic activities. Whereas, risk management according to Shariah is following the provisions of the Qur'an and the Sunnah of Prophet Muhammad (peace upon him) that promotes the preservation of wealth as one of the most important objectives of the Shariah. Islam recognizes that risk is common in business and prescribes ways on how to manage and minimize the risks (Dusuki, 2014).

Risk taking from Islamic perspectives is undesirable, even though it is an intrinsic part of economic activity. However, risk may create wealth and added value to the business. Hence, Shariah allows risk-taking activities because of the value it adds and the wealth it creates, and not because the risk is desirable. This distinction creates a fundamental difference between legitimate risk and forbidden risk. Risk is legitimate when it is necessary for the creation of value. However, when no value is created, risk is considered as a form of gambling (Bouslama \& Lahrichi, 2017). The main principles of risk management in Islam are to accept the correct proportions of risk in a normal part of a business equation and to internalize the fact that risk assumption, like profit making, is a natural expectation of investors in all business transactions (El-Khatib, 2009).

Shariah-compliant is the term used to describe a firm, in which its operation, financial, and investments activities conform to Islamic law. Securities Commission of Malaysia (SC) is the body responsible to undertake the stock screening process and granting Shariah-compliant status to those firms that apply for the status. SC uses two phases of screening process which are quantitative and qualitative assessments to screen firm's activities. Shariah Advisory Council (SAC) of the SC is responsible in assuming the stock screening processes. In general, Shariah-compliant status will be given to a firm whose business activities not involve in any of the following matters: (i) financial services based on riba, (ii) gambling, (iii) manufacturing or sale of non-halal (prohibited) products or related products, (iv) conventional insurance, (v) entertainment activities that are non-permissible according to Shariah, (vi) manufacturing or sale of tobacco-based products or related products, (vii) stock broking or share trading in nonShariah approved securities, and (viii) other activities deemed non-permissible according to Shariah. Public listed firms that have been granted the Shariah-compliant status are regarded as ethical firms that adopt and maintain higher standards in running their business activities.

Theoretical Framework and Hypotheses Development

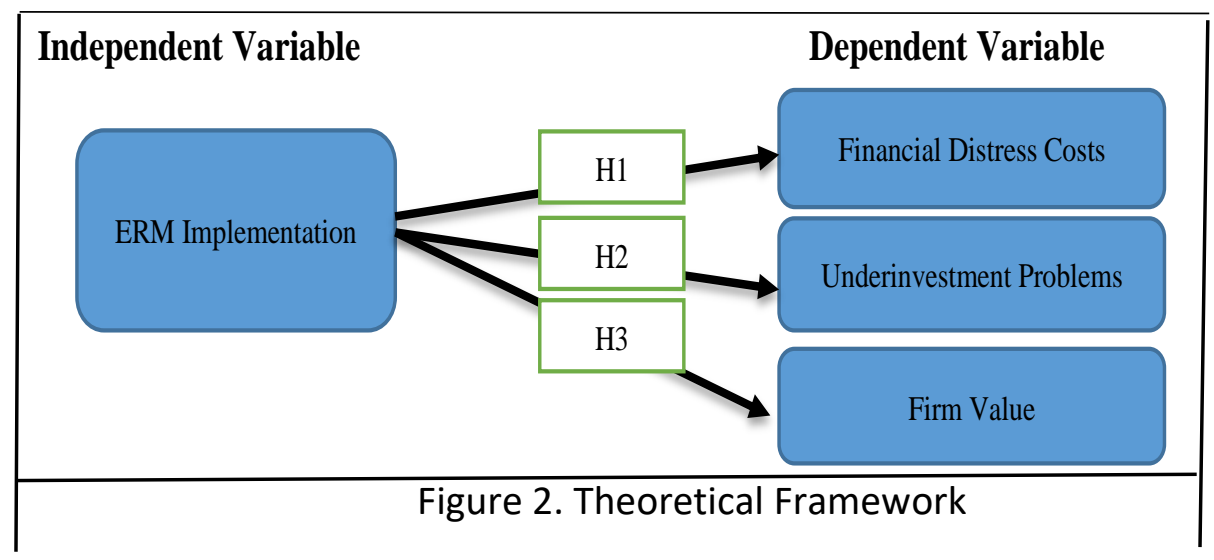

Figure 2 depicted the theoretical framework of this study that is developed based on shareholders value maximising theory which postulates that ERM implementation will lead to value creation for organizations (Lai \& Shad, 2017; Nocco et al., 2006; Stulz, 1996; Tufano, 
1996). In this study, ERM implementation is an independent variable, whereas the dependent variable is the shareholders value which are proxied by financial distress costs, underinvestment problems and firm value. In the research framework, it is shown that ERM implementation significantly affects shareholders value.

\section{Hypotheses Development}

\section{Financial Distress Costs}

Financial distress is defined as a situation where a firm has to give up positive net present value (NPV) activities because of financial constraints (Nocco \& Stulz, 2006). Risk management at the enterprise level is claims to increase the firm's value to shareholders by reducing costs associated with agency conflicts, external financing, financial distress, and taxes (Aretz et al., 2007). Stulz (1996) argues that risk management can be value creating if it is able to help firm avoid the direct and indirect costs associated with financial distress and bankruptcy. Furthermore, Mayers and Smith (1982) and Smith and Stulz (1985) argue that risk management reduces the likelihood of firm encountering financial distress by reducing the variance of firm value and thereby reducing the expected costs of financial distress. Beasley, Pagach, and Warr (2008) call for greater risk management activities as the possibility of the increase of transaction costs from financial distress and bankruptcy. Thus, when a firm is faced with the possibility of lower-tail outcomes, engaging in risk management activities would reduce the likelihood of real costs associated with such outcomes.

Khan, Hussain, and Mehmood (2016) investigate the factor that lead towards the decision of initiating an ERM programme among 315 of French firms. The results suggest that firm's internal factors such as the expected probability of financial distress and its explicit and implicit costs, poor earnings performance and the existence of growth opportunities play vital role in motivating firms to adopt ERM. Moreover, Krause and Tse (2016) state that recent empirical evidence provides support that risk management increases firm value and returns, while reducing return and cash flow volatility that reduces the possibility of firm facing with financial distress. Accordingly, the following hypothesis is asserted:

H1: There is a positive relationship between ERM implementation and financial distress costs.

\section{Underinvestment Problem}

Underinvestment problem is a situation when a firm has many growth options but cost of raising external financing is more expensive than fund generated internally to finance the investment. This problem arises when investment opportunities are negatively correlated with cash flows. In addition, Gay and Nam (1998) explain that an underinvestment problem appears when firms find that external financing is sufficiently expensive and investment spending needs to be reduced during times when internally generated cash flows are not sufficient to finance growth opportunities. In general, firms prefer to finance investments using internally generated fund such as retained earnings due to its lower cost as compared to a more costly external generated fund.

Froot, Scharfstein, and Stein (1993) develop a framework to understand factors that influence a firm's decision in implementing risk management and among the factors studied is the presence of costly external financing. The risk management framework shows that a firm's risk management activity can increase value by ensuring that a firm has sufficient cash flow available to make value enhancing investments. When raising external capital is costly due to transaction costs, firms may underinvest: thus, managers can use risk management to increase shareholder value by coordinating the need for and availability of internal funds. 
A credible risk management program can mitigate underinvestment costs by reducing the volatility of firm value and this problem seems more serious for firms with a significant growth and investment opportunities (Bartram, Brown, \& Conrad, 2011). Empirical studies provide mixed support for the underinvestment hypothesis. Studies by Géczy, Minton, and Schrand, (1997) and Nance, Smith, and Smithson (1993) find that firms with greater growth opportunities and tighter financial constraints are more likely to use risk management to reduce cash flow variation that might otherwise prevent firms from investing in valuable growth opportunities. However, (Mian, 1996) finds a negative relation between a firm's investment opportunities and its risk management tools, which does not support the underinvestment hypothesis. Thus, the following hypothesis is proposed:

H2: There is a positive relationship between ERM implementation and underinvestment problems.

\section{ERM and Firm Value}

The main goal of ERM is to maximise firm and shareholder value and a number of studies have done investigations based on this premise. The implementation of an ERM program that has a holistic perspective on a firm's risk portfolio is aims to enhance a firm's shareholders value (Lechner \& Gatzert, 2018). Kashif Shad and Lai (2019) and Lechner and Gatzert (2018) confirm a significant positive impact of ERM implementation on firm performance. Study by Hoyt and Liebenberg (2011) measures the extent to which firms have implemented ERM programs and assesses the value implications of the program found a positive relation between firm value and the use of ERM. Meanwhile, Pagach and Warr, (2010) studied the effect of adoption of ERM practices on firms' long-term performance by examining how financial, asset and market characteristics change around the time of ERM adoption. Findings show that some firms adopting ERM experience a reduction in earnings volatility. However, in general their result failed to find support for the proposition that ERM is value creating.

Izah and Ahmad Rizal (2011) are amongst the pioneer empirical researchers using Malaysia as their research setting. They estimated the relation between ERM and firm value in Malaysian public listed firms using data of 528 firms. Tobin's Q was employed as measurement of firm value. Empirically, the study does not support the hypothesis that firms which practice ERM would have a higher value than firms which are not. In a contrary, Ping and Muthuveloo, (2015) observed a significant influence of ERM implementation to firm value when examining the effect of ERM implementation on firm performance among 103 Malaysian PLCs. Due to mixed findings of previous studies, the current study hypothesizes that:

H3: There is a significant relationship between the extent of ERM implementation and firm value.

\section{Research Methodology and Data Analysis Sample Frame and Data Collection}

The main objective of the current study is to examine the impact of ERM implementation to shareholders value. Sample and unit of analysis of this study are publicly traded Malaysian Shariah-compliant firms. The sample is selected from the list of Shariah-compliant firms issued by the Shariah Advisory Council (SAC) of the Securities Commission Malaysia (SC). The population of this study is limited to publicly traded firms because of the availability of risk information that is reported for public use where information can be assessed through firm's annual reports. The population of Shariah-compliant firms listed by SC on 30 November 2013 
was around 817 and after excluding financial firms, the final population consists of 815 firms. Samples are selected from the population using simple random sampling method and based on the total population of 815 of Shariah-compliant public listed firms, the required sample size is 201 firms from seven industries.

This study uses two types of data: primary data; gathered through survey questionnaire and the main objective of collecting primary data was to measure the ERM implementation among the sample firms. This is a cross-sectional study where questionnaires were sent to Malaysian Shariah-compliant firms, which are listed on Bursa Malaysia at a single point of time. Survey questionnaires were sent to 201 respondents and one hundred and five responses were received; however, twenty-four of them were rejected and removed from the sample because the respondents left a substantial number of questions unanswered. Therefore, the final usable sample consists of 81 respondents, representing 40 percent of the sample. Upon completion of the first phase of data collection via survey questionnaire, the second phase of data collection was conducted. In the second phase, secondary data were hand-picked from annual reports of companies that were participated in the survey. This data is used to measure financial distress costs, underinvestment and firm value.

\section{Measurement of the Variables}

Theoretical framework of this study shows that firm value, financial distress costs and underinvestment problems serves as dependent variables. Firm value is measured using Tobin's Q. Tobin's $Q$ is defined as a ratio of market value of a firm to the replacement cost of its assets (Chung \& Pruitt, 1994). Hoyt and Liebenberg (2008) claim that Tobin's $Q$ is a standard proxy for firm value. Furthermore, Lindenberg and Ross (1981) argue that Tobin's $Q$ is a preferred measurement of firm value because Tobin's $Q$ reflects market expectations and is relatively free from managerial manipulation. Underinvestment problems was measured using the ratio of research and development expense to sales and financial distress costs measured by debt maturity ratio that is total long-term debt to total debt (Bartram, Brown, \& Fehle, 2009).

ERM implementation is an independent variable and was measured by using ERM Dimension index (ERMDi) (Maruhun, Atan, Yusuf, \& Said, 2018). ERM implementation is assessed using ERMDi that consists of eight principal dimensions and measured by 41 items. The ERM implementation was measured based on the data collected from questionnaire by using seven-point Likert scale of $1=$ strongly disagree and $7=$ strongly agree. Table 1 shows summary of variables and measurements. 
Table 1.

Summary of Variables and Measurements

\begin{tabular}{|c|c|c|}
\hline Variable Name & Measurement & Sources \\
\hline ERM Implementation & $\begin{array}{l}\text { - Ordinal variable based on } \\
\text { degree of } \\
\text { agreement/disagreement } \\
\text { on ERM implementation. } \\
\text { Measured using ERMDi }\end{array}$ & $\begin{array}{l}\text { COSO (2004) } \\
\text { ISO 31000:2009 } \\
\text { Maruhun et al., } \\
\text { (2018) }\end{array}$ \\
\hline Firm Value & $\begin{array}{l}\text { - } \quad \text { Q }=(\mathrm{MVE}+\text { Preference } \\
\text { Shares + Debt }) / \mathrm{TA}\end{array}$ & $\begin{array}{l}\text { Adapted from } \\
\text { Chung \& Pruitt } \\
\text { (1994) }\end{array}$ \\
\hline $\begin{array}{l}\text { Financial Distress Costs } \\
\text { Underinvestment problems }\end{array}$ & $\begin{array}{ll}\text { - } & \text { Total Long-Term } \\
\text { Debt/Total Debt }\end{array}$ & $\begin{array}{l}\text { Bartram, } \\
\text { Brown, \& } \\
\text { Conrad (2009) }\end{array}$ \\
\hline & $\begin{array}{l}\text { - } \quad \text { Research and development } \\
\text { expense/ Sales }\end{array}$ & $\begin{array}{l}\text { Bartram, } \\
\text { Brown, \& } \\
\text { Conrad (2009) }\end{array}$ \\
\hline
\end{tabular}

\section{Data Analysis}

Hypotheses testing was conducted to assess $\mathrm{H} 1, \mathrm{H} 2$ and $\mathrm{H} 3$. Based on shareholders value maximising theory, the impacts of ERM implementation to financial distress costs, underinvestment problems, and firm value were evaluated. To assess the impact of an independent variable (ERM implementation) to three dependent variables (financial distress costs, underinvestment problems, and firm value), this study applied the multivariate analysis of variance (MANOVA). MANOVA is an appropriate method of analysis when the model has more than one dependent variable, and the dependent variables are related in some way, or when there are some conceptual reasons for considering them together (Pallant, 2011). As for this study, dependent variables which are financial distress costs, underinvestment problem, and firm value are the variables used to measure shareholders value maximising. Prior to performing the MANOVA, the correlation test was conducted to determine the existence of any multicollinearity problem among the dependent variables which are financial distress costs, underinvestment problems, and firm value. One way of checking multicollinearity problem is using bivariate correlation analysis. According to Cooper and Schindler (2011), serious multicollinearity problems exist when the bivariate correlation score is 0.80 or greater. Spearman's rho correlation results show a significant relationship between financial distress costs and underinvestment problems; however, the correlation coefficient of .316 indicates that multicollinearity is absent because the value is lower than cut-off point of .80 as suggested by Cooper and Schindler (2011). Table 2 presents the result of the Spearman's rho correlation analysis among the three dependent variables. 
Table 2.

Spearman's rho Correlations Matric

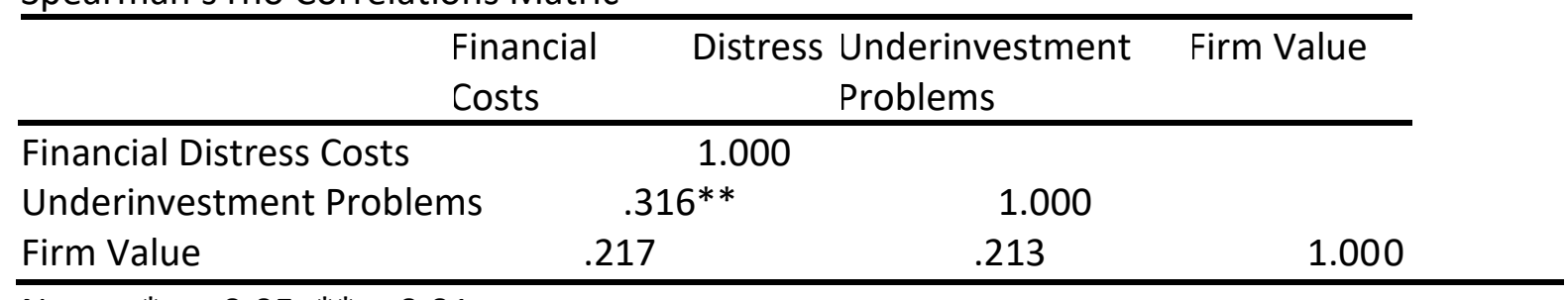

Notes: ${ }^{*} p<0.05, * * p<0.01$

After checking for multicollinearity problem among the dependent variables and the results are found to be satisfactory, the next process was conducting the MANOVA analysis. The multivariate regression results are presented in Table 3.

Table 3.

Results of Multivariate Regression Analysis (MANOVA)

\begin{tabular}{lccl}
\hline & Exp.Sign & $\mathbf{F}($ Wilks' $\lambda$ ) & Sig. \\
\hline Independent Variable: ERM & & & \\
Financial distress costs & + & 2.790 & $.032^{* *}$ \\
Underinvestment problems & + & 2.520 & $.048^{* *}$ \\
Firm value & + & 1.293 & .280 \\
Wilks' Lambda & & 1.798 & $0.051^{*}$ \\
Number of observations: 81 & & & \\
Adjusted $\mathrm{R}^{2}=0.13$ & & &
\end{tabular}

Notes: ${ }^{*} p<0.10,{ }^{* *} p<0.05$

A one-way multivariate analysis of variance was conducted to determine the impact of ERM implementation (independent variable) to shareholders value maximising. Three dependent variables which are financial distress costs, underinvestment problems, and firm value were used as proxy of shareholders value maximising. As discussed above, before the main analysis was conducted, a preliminary assumption testing was run to check multicollinearity problem and no serious violations were noted. Results of MANOVA analysis as shown in Table 3 revealed a statistically significant difference between ERM implementation on the combined dependent variables, Wilks' $\lambda(F)=1.798, p<.10$ and the adjusted $R^{2}$ is 13 percent. Further analysis for univariate ANOVAs showed that both financial distress costs $(F=2.790, p<0.05)$ and underinvestment problems $(F=2.520, p<0.05)$ were statistically significantly different to the extent of ERM implementation. The results provide empirical evidence supporting $\mathrm{H} 1$ and $\mathrm{H} 2$ confirming that ERM implementation has an impact on financial distress cost and underinvestment problems. However, no empirical evidence was observed to support $\mathrm{H} 3$ on the impact of ERM to firm value.

\section{Discussion and Conclusion}

The primary objectives of this study are (i) to evaluate whether ERM have an impact on shareholders value that are proxied by financial distress cost and underinvestment problem and (ii) to examine whether ERM creates value to Malaysian Shariah-compliant public listed firms. Three hypotheses were proposed to achieve the research objectives; $\mathrm{H} 1, \mathrm{H} 2$ and $\mathrm{H} 3$. Empirical results of the current study supporting $\mathrm{H} 1$ and $\mathrm{H} 2$, confirming that ERM 
implementation has an impact to financial distress cost and underinvestment problems. These findings are consistent with the theory stating that firms implement ERM program to mitigate financial distress costs and underinvestment problems (e.g. Jin \& Jorion, 2006; Mayers \& Smith, 1982; Smith \& Stulz, 1985). Graham and Rogers (2002) state that firms with higher debt ratios may face higher probabilities of encountering financial distress costs; thus, they implement greater risk management activities. Firms which are likely to face financial distress costs would be more inclined to implement more extensive risk management.

In addition, Lundqvist (2015) claims that firms with high levels of debt can face underinvestment problems, financial distress costs and difficulty when coordinating financing and investment strategies. Therefore, ERM can help firms mitigate the problems and at the same time firms are able to hold more debt due to decrease in the possibilities of financial distress. Hoyt and Liebenberg (2011) argue that firms with high levels of leverage may increase the probability of bankruptcy and incur extra costs because of increased financial distress. Therefore, through implementation of ERM, firms may have a lower possibility of facing bankruptcy costs.

Findings of the current study are consistent with Shariah's directives that firms need to implement a risk management activity, such as ERM program, to preserve their wealth. Even though, risks from Islamic perspectives represent the probable loss of wealth, which is not desirable, risk is essential in economic activities to create wealth and value. According to principles of maqasid, firms should take all precautions to safeguard their present and future wealth. One way to protect firms' wealth is to have risk management program that is able to mitigate financial distress costs and underinvestment problems. Firms can protect their wealth by implementing ERM program that is able to mitigate the risks. According to Shariah, risk management is important to achieve prudence in the use of resources and the avoidance of waste and damage, which includes economic waste and financial losses.

However, findings of this study do not find support to H3 and this indicates that ERM implementation does not have an impact on firm value among Malaysian Shariah-compliant public listed firms. Albeit, Shariah Law obliges firms to measure and manage risk in order to preserve the business current and future wealth, the impact of ERM implementation to the firm's value is not evidenced. A potential explanation could be that ERM is a growing risk management concept in Malaysia that requires expertise and high costs of implementation. ERM is an evolving concept of managing corporate risks; therefore, nurturing of a risk-aware culture within a firm is vital. ERM requires specialized knowledge and expertise on risk management; thus, there is a need for extensive training on risk management for firms. In order to implement ERM program, firms need to train their staff and top management about the system so that they have the skill to use the system effectively and efficiently. However, high training cost is one of the main factors that hinder ERM implementation among Malaysian firms.

To conclude, testing the three proposed hypotheses in this study provides a useful starting point in understanding ERM practices and its impact to a firm's value in Malaysian perspectives. The results from this study confirm that shareholder maximising theory is an important theory that could influence a firm to implement ERM. Two variables representing the shareholder maximising theory, which are financial distress cost and underinvestment problem, are both positively and significantly related to ERM implementation. Furthermore, this study may contribute new knowledge to ERM literature, results of this study could help academics and firms to have a better understanding on the impact of ERM implementation to shareholders value where empirical findings of this study confirmed that ERM 
implementation is able to increase shareholders value through reduction of financial distress cost and underinvestment problem.

\section{References}

Aabo, T., Fraser, J. R. S., \& Simkins, B. J. (2010). The rise and evolution of the chief risk officer: enterprise risk management at Hydro One. Journal of Applied Corporate Finance, 17(3), 62-75.

Agha, S. E. U., \& Sabirzyanov, R. (2015). Risk management in Islamic finance: an analysis from objectives of shari'ah perspective. International Journal of Business, Economics and Law, $7(3), 46-52$.

Ai, J., Chen, H., \& Zhao, Y. (2014). Does ERM improve firm value? evidence from listed Chinese nonfinancial SOEs. In Ssrn. https://doi.org/10.2139/ssrn.2538915

Altuntas, M., Berry-Stolzle, T. R., \& Hoyt, R. E. (2011). Implementation of enterprise risk management: Evidence from the German property-liability insurance industry. The Geneva Papers on Risk and Insurance-Issues and Practice, 36(3), 414-439.

Arena, M., Arnaboldi, M., \& Azzone, G. (2011). Is enterprise risk management real? Journal of Risk Research, 14, 779-797.

Bartram, S., Brown, G., \& Fehle, F. (2009). International evidence on financial derivatives usage. Financial Management, 38(1), 185-206.

Bartram, S. M., Brown, G. W., \& Conrad, J. (2011). The effects of derivatives on firm risk and value. Journal of Financial and Quantitative Analysis, 46(4), 967-999.

Baxter, R., Bedard, J., Hoitash, R., \& Yezegel, A. (2013). Enterprise risk management program quality: determinants, value relevance, and the financial crisis. Contemporary Accounting Research, 30(4), 1264-1295.

Beasley, M., Pagach, D., \& Warr, R. (2008). Information conveyed in hiring announcements of senior executives overseeing enterprise-wide risk management processes. Journal of Accounting, Auditing \& Finance, 23(3), 311-333.

Beasley, M., Branson, B., \& Pagach, D. (2015). An analysis of the maturity and strategic impact of investments in ERM. Journal of Accounting and Public Policy, 34(3), 219-243.

Betty, J. S., \& Steven, A. R. (2008). Enterprise-wide risk management and corporate governance. Loyola University Chicago Law Journal, 39, 571-594.

Bouslama, G., \& Lahrichi, Y. (2017). Uncertainty and risk management from Islamic perspective. Research in International Business and Finance, 39, 718-726.

Chung, K., \& Pruitt, S. (1994). A simple approximation of Tobin's q. Financial Management, 23(3), 70-74.

Cooper, D. R., \& Schindler, P. S. (2011). Business research method (11th ed.). McGrawHill/Irwin.

COSO. (2004). Enterprise risk management-integrated framework. In Committee of Sponsoring Organizations of the the Treadway Commission.

Daud, W. N. W. D., Yazid, A. S., \& Hussin, H. M. R. (2010). The effect of chief risk officer (CRO) on enterprise risk management (ERM) practices: Evidence from Malaysia. International Business \& Economics Research Journal (IBER), 9(11).

Dickinson, G. (2001). Enterprise risk management: Its origins and conceptual foundation. Geneva Papers on Risk and Insurance - Issues and Practice, 26(3), 360-366.

Dionne, G., \& Garand, M. (2003). Risk management determinants affecting firms' values in the gold mining industry: New empirical results. Economics Letters, 79(1), 43-52.

Dusuki, A. W. (2014). Principles and application of risk management and hedging instruments 
in Islamic finance. Retrieved from www.iefpedia.com/english/wpcontent/uploads/2012/07/Asyraf.pdf

El-Khatib, H. (2009). Harvard - LSE Workshop : Islamic Economic and Islamic Ethico - Legal Perspectives on the Current Financial Crisis.

Farrell, M., \& Gallagher, R. (2015). The valuation implications of enterprise risk management maturity. Journal of Risk and Insurance, 82(3), 625-657.

Froot, K. A., Scharfstein, D. S., \& Stein, J. C. (1993). Risk management: coordinating corporate investment and financing policies. The Journal of Finance, 48(5), 1629-1658.

Gatzert, N., \& Martin, M. (2015). Determinants and value of enterprise risk management: Empirical evidence from the literature. Risk Management and Insurance Review, 18(1), 29-53.

Géczy, C., Minton, B. A., \& Schrand, C. (1997). Why firms use currency derivatives. The Journal of Finance, $L I I(4), 1323-1354$.

Gordon, L. A., Loeb, M. P., \& Tseng, C.-Y. (2009). Enterprise risk management and firm performance : A contingency perspective. Journal of Accounting and Public Policy, 28(4), 301-327.

Graham, J. R., \& Rogers, D. A. (2002). Do firms hedge in response to tax incentives ? The Journal of Finance, LVII(2), 815-839.

Harner, M. M. (2010). Barriers to effective risk management. Seton Hall L. Rev., 1-36.

Hoyt, R. E., \& Liebenberg, A. P. (2008). The value of enterprise risk management : Evidence from the U.S. insurance industry.

Hoyt, R. E., \& Liebenberg, A. P. (2011). The value of enterprise risk management. Journal of Risk and Insurance, 78(4), 795-822.

Iswajuni, I., Manasikana, A., \& Soetedjo, S. (2018). The effect of enterprise risk management ( $E R M$ ) on firm value in manufacturing companies listed on Indonesian Stock Exchange year 2010-2013. Asian Journal of Accounting Research, 3(2), 224-235.

Izah, M. T., \& Rizal, A. R. (2011). The relationship between enterprise risk management (ERM) and firm value: Evidence form Malaysian public listed companies. International Journal of Economics and Management Sciences, 1(2), 32-41.

Jin, Y., \& Jorion, P. (2006). Firm value and hedging : Evidence from U.S. oil and gas producers. The Journal of Finance, LXI(2), 893-920.

Shad, K. M., \& Lai, F.-W. (2019). Enterprise risk management implementation and firm performance: Evidence from the Malaysian oil and gas industry. International Journal of Business and Management, 14(9), 47.

Khan, M. J., Hussain, D., \& Mehmood, W. (2016). Why do firms adopt enterprise risk management (ERM)? empirical evidence from France. Management Decision, 54(8), 1886-1907.

Krause, T. A., \& Tse, Y. (2016). Risk management and firm value: Recent theory and evidence. International Journal of Accounting and Information Management, 24(1), 56-81.

Lai, F.-W., \& Shad, K. M. (2017). Economic value added analysis for enterprise risk management. Global Business and Management Research: An International Journal, 9(1s), 338-347.

Lam, J. (2014). Enterprise risk managment: From incentives to controls (second edi). John Wiley \& Sons, Inc.

Lechner, P., \& Gatzert, N. (2018). Determinants and value of enterprise risk management: empirical evidence from Germany. The European Journal of Finance, 24, 867-887.

Liebenberg, A. P., \& Hoyt, R. E. (2003). The determinants of enterprise risk management: 
Evidence from the appointment of chief risk officers. Risk Management and Insurance Review, 6(1), 37-52.

Lin, Y., Wen, M. M., \& Yu, J. (2012). Enterprise risk management: Strategic antecedents, risk integration, and performance. North American Actuarial Journal, 16(1), 1-28.

Lindenberg, E. B., \& Ross, S. A. (1981). Tobin's q ratio and industrial organization. The Journal of Business, 54(1), 1-32.

Lundqvist, S. A. (2014). An exploratory study of enterprise risk management : Pillars of ERM. Journal of Accounting, Auditing, and Finance, 29(3), 393-429.

Lundqvist, S. A. (2015). Why firms implement risk governance - Stepping beyond traditional risk management to enterprise risk management. Journal of Accounting and Public Policy, 34(5), 441-466.

Marc, M., Sprčić, D. M., \& Žagar, M. M. (2018). Is enterprise risk management a value added activity? Ekonomie a Management, 21(1), 68-84.

Maruhun, E. N. S., Atan, R., Yusuf, S. N. S., \& Said, J. (2018). Developing enterprise risk management index for Shariah-compliant companies. Global Journal Al Thaqafah, 8(1), 189-205.

Mayers, D., \& Smith, C. W. (1982). On the corporate demand for insurance. Journal of Business, 55(2), 281-296.

McShane, M. K., Nair, A., \& Rustambekov, E. (2011). Does enterprise risk management increase firm value. Journal of Accounting, Auditing, and Finance, 26(4), 641-658.

Mian, S. L. (1996). Evidence on corporate hedging policy. Journal of Financial and Quantitative Analysis, 31(3), 419-439.

Miccolis, J., \& Shah, S. (2000). Enterprise risk management: An analytic approach. In Tillinghast-Towers Perrin.

Miller, K. D. (1992). A Framework for Integrated Risk Management in International Business. Journal of International Business Studies, 23(2), 311-331.

Nance, D. R., Smith, C. W., \& Smithson, C. W. (1993). On the determinants of corporate hedging. The Journal of Finance, 48(1), 267-284.

Nocco, B. W., \& Stulz, R. M. (2006). Enterprise risk management: theory and practice. Journal of Applied Corporate Finance, 18(4), 8-20.

OECD. (2014). Risk management and corporate governance. OECD Publishing.

Pagach, D., \& Warr, R. (2010). The effects of enterprise risk management on firm performance the effects of enterprise risk management on firm performance. management, 45(April), $65-66$.

Pallant, J. F. (2011). SPSS Survival Manual. In Allen \& Unwin (4th editio). Allen \& Unwin.

Ping, T. A., \& Muthuveloo, R. (2015). The impact of enterprise risk management on firm performance : Evidence from Malaysia. Asian Social Science, 11(22), 149-159.

Quon, T. K., Zeghal, D., \& Maingot, M. (2012). Enterprise Risk Management and Firm Performance. Procedia - Social and Behavioral Sciences, 62, 263-267.

Shenkir, W. G., \& Walker, P. L. (2008). Enterprise risk management : Frameworks, elements and integration.

Simkins, B., \& Ramirez, S. (2008). Enterprise-wide risk management and corporate governance. Loyola University Chicago Law Journal, 39, 571-594.

Smith, C. W., \& Stulz, R. M. (1985). The determinants of firms' hedging policies. Journal of Finance and Quantitative Analysis, 20(4), 391-406.

Sobel, P., \& Reding, K. (2004). Aligning corporate governance with enterprise risk management. Management Accounting Quartely, 5(2), 29-38. 
Songling, Y., Ishtiaq, M., \& Anwar, M. (2018). Enterprise risk management practices and firm performance, the mediating role of competitive advantage and the moderating role of financial literacy. Journal of Risk and Financial Management, 11(3), 35.

Stulz, R. M. (1996). Rethinking Risk Management. Journal of Applied Corporate Finance, 9(3), $8-25$.

Tufano, P. (1996). Who manages risk? An empirical examination of risk management practices in the gold mining industry. The Journal of Finance, 51(4), 1097-1137. 